\title{
PENINGKATAN KEMAMPUAN MENGGUNAKAN EJAAN DAN \\ TANDA BACA DALAM MENULIS PENGALAMAN PRIBADI DENGAN TEKNIK $J I G S A W$ SISWA KELAS VII-B SMP NEGERI 1 RENGEL KABUPATEN TUBAN
}

\author{
Heri Kustomo \\ SMP Negeri 1 Rengel Kabupaten Tuban \\ kustomoheri@gmail.com
}

\begin{abstract}
The research problem is the low ability students at class VII-B SMP Negeri 1 Rengel Tuban in using spelling and punctuation to write personal experience. It is seen from the data: 1) errors capitalization $89.65 \%$, 2) misuse of prepositions $86.20 \%$, 3) misapplication dot $75.86 \%$, and 4) error use commas $41.37 \%$.

Researchers chose Jigsaw technique to overcome the problems. This selection was based on the advantages of Jigsaw technique is to learn together, the problems faced by students can be resolved.

Results of the study: There was an increase in the ability to use correct spelling and punctuation in writing personal experience of students of class VII-B SMP Negeri 1 Rengel Tuban, namely: 1) errors capitalization decreased by $41.38 \%$ from $82.75 \%$ to $41,37 \%$, 2) misuse of prepositions decreased by $13.80 \%$ from $79.31 \%$ to $65.51 \%$, and 3) the use of punctuation errors decreased by $75.86 \%$ from $82.75 \%$ to $6.89 \%$.
\end{abstract}

Keywords: Using spelling and punctuation, write personal experience, Jigsaw technique.

\begin{abstract}
Abstrak
Permasalahan penelitian ini adalah rendahnya kemampuan siswa kelas VIIB SMP Negeri 1 Rengel Kabupaten Tuban dalam menggunakan ejaan dan tanda baca untuk menuliskan pengalaman pribadi. Hal tersebut dilihat dari data: 1) kesalahan penggunaan huruf kapital $89,65 \%, 2$ ) kesalahan penggunaan kata depan $86,20 \%$, 3) kesalahan penggunaan tanda titik $75,86 \%$, dan 4) kesalahan penggunaan tanda koma $41,37 \%$.

Peneliti memilih teknik Jigsaw untuk mengatasi permasalahan. Pemilihan ini didasarkan pada keunggulan-keunggulan teknik Jigsaw yaitu dengan belajar bersama, permasalahan yang dihadapi siswa dapat teratasi.

Hasil dari penelitian: Terjadi peningkatan kemampuan menggunakan ejaan dan tanda baca dalam menulis pengalaman pribadi siswa kelas VII-B SMP Negeri 1 Rengel Kabupaten Tuban yaitu: 1) kesalahan penggunaan huruf kapital menurun sebesar $41,38 \%$ yaitu dari $82,75 \%$ menjadi $41,37 \%, 2$ ) kesalahan penggunaan kata depan menurun sebesar $13,80 \%$ yaitu dari $79,31 \%$ menjadi $65,51 \%$, dan 3 ) kesalahan penggunaan tanda baca menurun sebesar $75,86 \%$ yaitu dari $82,75 \%$ menjadi $6,89 \%$.
\end{abstract}

Kata Kunci: ejaan dan tanda baca, menulis pengalaman pribadi, teknik Jigsaw. 


\section{PENDAHULUAN}

Pembelajaran bahasa Indonesia di Kelas VII-B SMP Negeri 1 Rengel Kabupaten Tuban pada kompetensi dasar 4.1 "menulis buku harian atau pengalaman pribadi dengan memperhatikan cara pengungkapan dan bahasa yang baik dan benar", menunjukkan kendala yaitu masih banyaknya siswa melakukan kesalahan penggunaan ejaan dan tanda baca pada waktu menulis pengalaman pribadi. Setelah produk berupa tulisan pengalaman pribadi siswa dikoreksi guru hasilnya adalah: 1) kesalahan penggunaan huruf besar/kecil 89,65\%, 2) kesalahan penggunaan kata depan 86,20\%, 3) kesalahan penulisan kata ulang 20,68\%, 4) kesalahan penggunaan tanda titik 75,86\%, dan 5) kesalahan penggunaan tanda koma 41,37\% (Data selengkapnya dapat dilihat pada lampiran 1).

Pembelajaran menulis di SMP menurut Riyanto (2006:180) memiliki tujuan antara lain: siswa dapat melakukan berbagai kegiatan menulis untuk mengungkapkan pikiran, perasaan, dan informasi dalam bentuk buku harian, surat pribadi, pesan singkat, laporan, surat dinas, petunjuk, rangkuman, teks berita, slogan, poster, iklan baris, resensi, karangan, karya ilmiah sederhana, pidato, surat pembaca, dan berbagai karya sastra berbentuk pantun, dongeng, puisi, drama, dan cerpen.

Aktivitas menulis tidak hanya berkaitan dengan tertuangnya ide dalam bentuk tulisan. Masalah penggunaan ejaan dan tanda baca dalam menulis juga merupakan salah satu syarat agar tulisan tersebut dapat mengkomunikasikan gagasan penulis kepada pembaca. Oleh karena itu, di dalam pembelajaran menulis siswa perlu dibiasakan untuk dapat memahami kaidah penggunaan ejaan dan tanda baca sesuai dengan EYD dan menerapkannya dalam praktik menulis.

Paradigma pembelajaran bahasa dalam KTSP, secara eksplisit tidak lagi menerapkan pembelajaran struktur ketatabahasaan. Pandangan tentang "belajar berbahasa adalah belajar berkomunikasi" dianggap paling tepat. Akan tetapi sebagai ekses lepasnya materi struktur ketatabahasaan dalam pembelajaran, sekarang muncul penafian kaidah ejaan dan tanda baca oleh siswa. 
Secara implisit, pembelajaran bahasa Indonesia diharapkan menjadi suatu wahana untuk menanamkan kaidah penggunaan ejaan dan tanda baca yang tepat sesuai dengan pedoman ejaan yang disempurnakan (EYD). Hal tersebut sebagaimana dikemukakan Yulianto (2008:2) bahwa pembelajaran berbahasa harus lebih berorientasi pada pembelajaran berbahasa, bukan pembelajaran bahasa. Oleh karena itu pembelajaran berbahasa harus diarahkan kepada berlatih berbahasa secara nyata. Misalnya dalam menulis, bahasa yang digunakan tidak boleh seenaknya tanpa mengindahkan kaidah ketatabahasaan.

Yulianto (2008:7) juga mengingatkan kepada guru bahwa pembelajaran aspek kebahasaan termasuk ejaan dan tanda baca baru dibahas di kelas pada waktu guru menemukan kesalahan berbahasa pada diri siswa baik dalam bahasa lisan maupun tulisan. Hal inilah yang membuat pembelajaran aspek kebahasaan menjadi tidak terstruktur dan tidak terbatas. Pembelajaran tata bahasa bukan merupakan hal yang utama dalam pembelajaran bahasa. Apabila siswa melakukan kesalahan ketatabahasaan, guru harus dapat menyadarkan siswa agar mengetahui kesalahan yang dilakukan tersebut sekaligus berupaya membetulkannya sesuai dengan kaidah.

Ejaan memiliki pengertian yang beraneka ragam antara lain dikemukakan oleh Yulianto (2008:20) "ejaan tidak menyangkut pada pelafalan kata. Ejaan menyangkut cara penulisan. Ejaan merupakan cara menuliskan bahasa (kata atau kalimat) menggunakan huruf dan tanda baca”.

Hasnun (2006:191) menyatakan bahwa menulis pengalaman adalah menulis apa yang dialami, dirasakan, dikerjakan dalam berbagai kegiatan. Penuangan pengalaman pribadi secara tertulis dapat dilakukan dengan berbagai cara antara lain dalam bentuk narasi. Hal ini sesuai dengan pendapat Afra (2007:97) "Kebanyakan orang memahami bahwa narasi identik dengan fiksi, sebenarnya tidak juga karena biografi, otobiografi ataupun kisahkisah sejati pun seringkali dibentuk sebagai sebuah narasi."

O’Malley dan Pierce (1996:37) berpendapat bahwa narasi merupakan wujud ekspresi atau imajinasi seseorang dalam menghasilkan cerita. Hal ini 
sering kali didasarkan pada pengamatan terhadap orang, objek, dan tempat, namun mungkin juga merupakan spekulasi dan interpretasi secara kreatif dari semua yang diamati penulis.

Keterampilan menulis tidak hanya berhubungan dengan keterampilan menuangkan gagasan dalam bentuk tulisan. Proses mewujudkan tulisan yang berkualitas baik, harus memenuhi berbagai persyaratan. Hal ini sebagaimana dikemukakan Suparno dan Yunus (2003:1.5) bahwa kegiatan menulis menuntut seseorang memiliki keterampilan mekanik antara lain penerapan kaidah ejaan, bagaimana melakukan pemilihan kata secara tepat, cara penyusunan kalimat efektif, cara penyusunan paragraf yang koheren, dan kesatuan ide dalam menyusun sebuah wacana.

Permasalahan ejaan dan tanda baca acap kali dipandang sebagai permasalahan yang sepele. Namun, dalam praktiknya masih banyak terjadi kesalahan. Hal ini sebagaimana dikemukakan Hasnun (2006:16) bahwa usia EYD sudah lebih dari dua dasawarsa. Akan tetapi, sampai sekarang masih dijumpai banyak kesalahan penggunaan ejaan dan tanda baca. Kesalahan tersebut juga banyak dijumpai dalam karangan-karangan ilmiah dan suratsurat resmi.

Permasalah penggunaan ejaan dan tanda baca dalam menulis pengalaman pribadi pada siswa Kelas VII-B SMP Negeri 1 Rengel Kabupaten perlu dipecahkan dengan teknik Jigsaw yang digagas oleh Elliot. Menurut Slavin (1995:122) inti dari gagasan Elliot ini adalah menyadari betapa pentingnya pembelajaran secara kooperatif. Teman satu kelas bukanlah rival yang harus selalu dikalahkan atau mengalahkan teman lain. Pembelajaran di kelas merupakan wahana untuk dapat menjalin kerja sama antarsiswa. Tidak ada kelas yang benar-benar homogen. Heterogenitas kelas, justru merupakan peluang untuk saling memberi dan menerima, antara siswa yang memiliki pengetahuan lebih dan siswa yang berpengetahuan kurang.

Lie (2003:66) mengemukakan bahwa proses pembelajaran dengan teknik jigsaw mensyaratkan guru untuk memperhatikan latar belakang pengalaman siswa dan membantu siswa untuk mengaktifkan kemampuan awal yang telah dimiliki 
agar pembelajaran menjadi lebih bermakna. Pelaksanaan teknik jigsaw memberikan kesempatan siswa untuk melakukan kerja sama sehingga membuka peluang untuk mengolah informasi dan meningkatkan keterampilan berkomunikasi.

Teknik jigsaw dalam praktiknya dapat dikembangkan dengan membentuk tim ahli. Sebelum melaksanakan tugas, siswa yang dianggap memiliki kemampuan tinggi pada masing-masing kelompok dipanggil ke depan untuk diberikan bekal pengetahuan tentang ejaan dan tanda baca. Setelah para siswa yang tergabung dalam tim ahli ini mendapatkan bekal dari guru, para siswa tersebut kembali ke kelompoknya untuk membimbing teman-temannya.

Penelitian Tindakan Kelas ini dilaksanakan pada bulan Maret 2012. Subjek dalam penelitian ini adalah siswa kelas VII-B SMP Negeri 1 Rengel Kabupaten Tuban berjumlah 30 anak, terdiri dari 14 laki-laki dan 16 perempuan.

Data yang dibutuhkan dalam penelitian ini bersumber pada pembelajaran antara lain: 1) Aktivitas siswa dalam mengikuti pembelajaran, 2) Aktivitas siswa ketika mengoreksi kesalahan ejaan dan tanda baca pada produk pengalaman pribadi milik temannya, 3) Produk berupa lembar pengalaman pribadi siswa.

Teknik pengumpulan data yang dilakukan dalam penelitian ini adalah: 1) Observasi, 2) Angket, 3) Penugasan menulis pengalaman pribadi, 4) Catatan Lapangan. Instrumen yang dibutuhkan dalam penelitian ini adalah sebagai berikut: 1) Lembar kerja siswa (LKS) untuk menulis pengalaman pribadi, 2) Lembar observasi untuk mengamati aktivitas siswa dalam pembelajaran, 3) Lembar angket untuk menjaring permasalahan-permasalahan yang dialami siswa dalam pembelajaran menulis pengalaman pribadi dengan teknik Jigsaw, 4) Catatan lapangan berisi catatan tentang segala sesuatu aktivitas siswa yang dianggap menarik dalam pembelajaran, 5) Rubrik untuk menilai kemampuan siswa dalam menggunakan ejaan dan tanda baca.

Teknik analisis data adalah sebagai berikut:

a. Observasi

$$
\frac{\text { banyak tanda cek " } y a^{"}}{\text { banyak pertanyaan }} \times 100=\cdots
$$


b.Angket

$$
\frac{\text { perolehan skor }}{\text { skor maksimal }} \times 100=\cdots
$$

c. Produk berupa pengalaman pribadi siswa

$$
\bar{X}=\frac{\sum X}{N}
$$

\section{DATA HASIL PENELITIAN}

Data hasil penelitian dapat dilihat pada tabel-tabel berikut:

\section{Hasil Siklus I}

\section{Tabel 1}

Data Kesalahan Penggunaan Huruf Kapital dalam Menulis Pengalaman Pribadi

\begin{tabular}{|c|c|c|}
\hline No & Nama & $\begin{array}{l}\text { Kesalahan penggunaan huruf } \\
\text { kapital/kecil }\end{array}$ \\
\hline 1 & Aan Purnomo & \\
\hline 2 & A. Zulfan Baharuddin & 15 \\
\hline 3 & Alfiano Yanuar E. & 14 \\
\hline 4 & Arinda Ririn W. & 8 \\
\hline 5 & Arum Mita Elfani & 1 \\
\hline 6 & Cinta Damayanti & - \\
\hline 7 & Dewi Nur Cahyani & 1 \\
\hline 8 & Easter Victoria G. & 7 \\
\hline 9 & Elang Bangkit M. & 40 \\
\hline 10 & Ferdi Dwi Alfianto & 14 \\
\hline 11 & Galuh Indra P. & 21 \\
\hline 12 & Hendrik Arianto & - \\
\hline 13 & Herliana Helda Y. & 29 \\
\hline 14 & Intan Madya Kumala S. & - \\
\hline 15 & Kabul Budiono & 10 \\
\hline 16 & M. Rizkur Rofiq & 5 \\
\hline 17 & Melani Santoso & 11 \\
\hline 18 & M. Wais Alqorni & 6 \\
\hline 19 & M. Priyanto & 19 \\
\hline 20 & Mustika Icha Kurnia & 6 \\
\hline 21 & Putri Ayu Afriariska & - \\
\hline 22 & Qomarul Fitriani & 3 \\
\hline 23 & Qurrota'Ayun & 3 \\
\hline 24 & Rizky Amalia Sari & 5 \\
\hline 25 & Ronaldo Candra Wijaya & - \\
\hline 26 & Siti Anita Indriyani & 1 \\
\hline 27 & Siti Sri Wahyuningsih & 24 \\
\hline
\end{tabular}
Siswa Kelas VII-B SMP Negeri 1 Rengel Kabupaten Tuban 


\begin{tabular}{|c|l|c|}
\hline 28 & Sony Budiarso & 19 \\
\hline 29 & Vicho Fahmi & 41 \\
\hline 30 & Zahro Qoryatina Putri & 2 \\
\hline \multicolumn{2}{|c|}{ Jumlah } & 305 \\
\hline
\end{tabular}

Tabel 2

Data Kesalahan Penggunaan Kata Depan dalam Menulis Pengalaman Pribadi Siswa Kelas VII-B SMP Negeri 1 Rengel Kabupaten Tuban

\begin{tabular}{|c|c|c|}
\hline No & Nama & Kesalahan penggunaan kata depan \\
\hline 1 & Aan Purnomo & \\
\hline 2 & B. Zulfan Baharuddin & 7 \\
\hline 3 & Alfiano Yanuar E. & - \\
\hline 4 & Arinda Ririn W. & 2 \\
\hline 5 & Arum Mita Elfani & 1 \\
\hline 6 & Cinta Damayanti & - \\
\hline 7 & Dewi Nur Cahyani & 3 \\
\hline 8 & Easter Victoria G. & - \\
\hline 9 & Elang Bangkit M. & 1 \\
\hline 10 & Ferdi Dwi Alfianto & - \\
\hline 11 & Galuh Indra P. & 3 \\
\hline 12 & Hendrik Arianto & 3 \\
\hline 13 & Herliana Helda Y. & 2 \\
\hline 14 & Intan Madya Kumala S. & 6 \\
\hline 15 & Kabul Budiono & 1 \\
\hline 16 & M. Rizkur Rofiq & 8 \\
\hline 17 & Melani Santoso & 3 \\
\hline 18 & M. Wais Alqorni & 8 \\
\hline 19 & M. Priyanto & 4 \\
\hline 20 & Mustika Icha Kurnia & 2 \\
\hline 21 & Putri Ayu Afriariska & - \\
\hline 22 & Qomarul Fitriani & 1 \\
\hline 23 & Qurrota 'Ayun & 2 \\
\hline 24 & Rizky Amalia Sari & 1 \\
\hline 25 & Ronaldo Candra Wijaya & 1 \\
\hline 26 & Siti Anita Indriyani & 4 \\
\hline 27 & Siti Sri Wahyuningsih & 1 \\
\hline 28 & Sony Budiarso & - \\
\hline 29 & Vicho Fahmi & 1 \\
\hline 30 & Zahro Qoryatina Putri & 6 \\
\hline \multicolumn{2}{|r|}{ Jumlah } & 71 \\
\hline
\end{tabular}


Tabel 3

Data Kesalahan Penggunaan Tanda Baca dalam Menulis Pengalaman Pribadi Siswa Kelas VII-B SMP Negeri 1 Rengel Kabupaten Tuban

\begin{tabular}{|c|c|c|}
\hline No & Nama & Kesalahan penggunaan tanda titik \\
\hline 1 & Aan Purnomo & \\
\hline 2 & C. Zulfan Baharuddin & 4 \\
\hline 3 & Alfiano Yanuar E. & - \\
\hline 4 & Arinda Ririn W. & 2 \\
\hline 5 & Arum Mita Elfani & 2 \\
\hline 6 & Cinta Damayanti & 2 \\
\hline 7 & Dewi Nur Cahyani & - \\
\hline 8 & Easter Victoria G. & - \\
\hline 9 & Elang Bangkit $\mathrm{M}$. & 9 \\
\hline 10 & Ferdi Dwi Alfianto & 4 \\
\hline 11 & Galuh Indra P. & 7 \\
\hline 12 & Hendrik Arianto & 1 \\
\hline 13 & Herliana Helda Y. & 4 \\
\hline 14 & Intan Madya Kumala S. & 1 \\
\hline 15 & Kabul Budiono & 2 \\
\hline 16 & M. Rizkur Rofiq & 1 \\
\hline 17 & Melani Santoso & 10 \\
\hline 18 & M. Wais Alqorni & 2 \\
\hline 19 & M. Priyanto & 6 \\
\hline 20 & Mustika Icha Kurnia & 1 \\
\hline 21 & Putri Ayu Afriariska & 4 \\
\hline 22 & Qomarul Fitriani & 2 \\
\hline 23 & Qurrota'Ayun & 4 \\
\hline 24 & Rizky Amalia Sari & 2 \\
\hline 25 & Ronaldo Candra Wijaya & - \\
\hline 26 & Siti Anita Indriyani & 6 \\
\hline 27 & Siti Sri Wahyuningsih & 2 \\
\hline 28 & Sony Budiarso & 1 \\
\hline 29 & Vicho Fahmi & - \\
\hline 30 & Zahro Qoryatina Putri & 10 \\
\hline \multicolumn{2}{|r|}{ Jumlah } & 89 \\
\hline
\end{tabular}


Tabel 4

Rekapitulasi Data Kesalahan Penggunaan Ejaan dan Tanda Baca dalam Menulis Pengalaman Pribadi

Siswa Kelas VII-B SMP Negeri 1 Rengel Kabupaten Tuban

\begin{tabular}{|c|c|c|c|c|c|}
\hline \multirow{2}{*}{ No } & \multirow{2}{*}{ Nama } & \multicolumn{3}{|c|}{ Kesalahan } & \multirow{2}{*}{ Jumlah } \\
\hline & & 1 & 2 & 3 & \\
\hline 1 & Aan Purnomo & & & & \\
\hline 2 & D. Zulfan Baharuddin & 15 & 7 & 4 & 26 \\
\hline 3 & Alfiano Yanuar E. & 14 & - & - & 14 \\
\hline 4 & Arinda Ririn W. & 8 & 2 & 2 & 12 \\
\hline 5 & Arum Mita Elfani & 1 & 1 & 2 & 4 \\
\hline 6 & Cinta Damayanti & - & - & 2 & 2 \\
\hline 7 & Dewi Nur Cahyani & 1 & 3 & - & 4 \\
\hline 8 & Easter Victoria G. & 7 & - & - & 7 \\
\hline 9 & Elang Bangkit M. & 40 & 1 & 9 & 50 \\
\hline 10 & Ferdi Dwi Alfianto & 14 & - & 4 & 18 \\
\hline 11 & Galuh Indra P. & 21 & 3 & 7 & 31 \\
\hline 12 & Hendrik Arianto & - & 3 & 1 & 4 \\
\hline 13 & Herliana Helda Y. & 29 & 2 & 4 & 35 \\
\hline 14 & Intan Madya Kumala S. & - & 6 & 1 & 7 \\
\hline 15 & Kabul Budiono & 10 & 1 & 2 & 13 \\
\hline 16 & M. Rizkur Rofiq & 5 & 8 & 1 & 14 \\
\hline 17 & Melani Santoso & 11 & 3 & 10 & 24 \\
\hline 18 & M. Wais Alqorni & 6 & 8 & 2 & 16 \\
\hline 19 & M. Priyanto & 19 & 4 & 6 & 29 \\
\hline 20 & Mustika Icha Kurnia & 6 & 2 & 1 & 9 \\
\hline 21 & Putri Ayu Afriariska & - & - & 4 & 4 \\
\hline 22 & Qomarul Fitriani & 3 & 1 & 2 & 6 \\
\hline 23 & Qurrota'Ayun & 3 & 2 & 4 & 9 \\
\hline 24 & Rizky Amalia Sari & 5 & 1 & 2 & 8 \\
\hline 25 & Ronaldo Candra Wijaya & - & 1 & - & 1 \\
\hline 26 & Siti Anita Indriyani & 1 & 4 & 6 & 11 \\
\hline 27 & Siti Sri Wahyuningsih & 24 & 1 & 2 & 27 \\
\hline 28 & Sony Budiarso & 19 & - & 1 & 20 \\
\hline 29 & Vicho Fahmi & 41 & 1 & - & 42 \\
\hline 30 & Zahro Qoryatina Putri & 2 & 6 & 10 & 18 \\
\hline & Jumlah & 305 & 71 & 89 & \\
\hline
\end{tabular}

\section{Keterangan:}

1. Kesalahan penggunaan huruf kapital/kecil

2. Kesalahan penggunaan kata depan

3. Kesalahan penggunaan tanda baca 
2. Hasil Siklus II

Tabel 5

Data Kesalahan Penggunaan Huruf Kapital dalam Menulis Pengalaman Pribadi

Siswa Kelas VII-B SMP Negeri 1 Rengel Kabupaten Tuban

\begin{tabular}{|c|c|c|}
\hline No & Nama & $\begin{array}{c}\text { Kesalahan penggunaan huruf } \\
\text { kapital/kecil }\end{array}$ \\
\hline 1 & Aan Purnomo & \\
\hline 2 & E. Zulfan Baharuddin & 2 \\
\hline 3 & Alfiano Yanuar E. & - \\
\hline 4 & Arinda Ririn W. & - \\
\hline 5 & Arum Mita Elfani & - \\
\hline 6 & Cinta Damayanti & - \\
\hline 7 & Dewi Nur Cahyani & - \\
\hline 8 & Easter Victoria G. & - \\
\hline 9 & Elang Bangkit M. & 5 \\
\hline 10 & Ferdi Dwi Alfianto & - \\
\hline 11 & Galuh Indra P. & 3 \\
\hline 12 & Hendrik Arianto & - \\
\hline 13 & Herliana Helda Y. & 2 \\
\hline 14 & Intan Madya Kumala S. & - \\
\hline 15 & Kabul Budiono & 7 \\
\hline 16 & M. Rizkur Rofiq & 2 \\
\hline 17 & Melani Santoso & - \\
\hline 18 & M. Wais Alqorni & 1 \\
\hline 19 & M. Priyanto & - \\
\hline 20 & Mustika Icha Kurnia & - \\
\hline 21 & Putri Ayu Afriariska & 2 \\
\hline 22 & Qomarul Fitriani & - \\
\hline 23 & Qurrota 'Ayun & 1 \\
\hline 24 & Rizky Amalia Sari & - \\
\hline 25 & Ronaldo Candra Wijaya & 1 \\
\hline 26 & Siti Anita Indriyani & 2 \\
\hline 27 & Siti Sri Wahyuningsih & - \\
\hline 28 & Sony Budiarso & 1 \\
\hline 29 & Vicho Fahmi & - \\
\hline 30 & Zahro Qoryatina Putri & - \\
\hline \multicolumn{2}{|r|}{ Jumlah } & 29 \\
\hline
\end{tabular}


Tabel 6

Data Kesalahan Penggunaan Kata Depan

dalam Menulis Pengalaman Pribadi

Siswa Kelas VII-B SMP Negeri 1 Rengel Kabupaten Tuban

\begin{tabular}{|c|c|c|}
\hline No & Nama & Kesalahan penggunaan kata depan \\
\hline 1 & Aan Purnomo & \\
\hline 2 & F. Zulfan Baharuddin & 2 \\
\hline 3 & Alfiano Yanuar E. & 1 \\
\hline 4 & Arinda Ririn W. & - \\
\hline 5 & Arum Mita Elfani & 1 \\
\hline 6 & Cinta Damayanti & - \\
\hline 7 & Dewi Nur Cahyani & 1 \\
\hline 8 & Easter Victoria G. & - \\
\hline 9 & Elang Bangkit $\mathrm{M}$. & 3 \\
\hline 10 & Ferdi Dwi Alfianto & 2 \\
\hline 11 & Galuh Indra P. & 1 \\
\hline 12 & Hendrik Arianto & 2 \\
\hline 13 & Herliana Helda Y. & 1 \\
\hline 14 & Intan Madya Kumala S. & - \\
\hline 15 & Kabul Budiono & - \\
\hline 16 & M. Rizkur Rofiq & - \\
\hline 17 & Melani Santoso & 1 \\
\hline 18 & M. Wais Alqorni & 5 \\
\hline 19 & M. Priyanto & - \\
\hline 20 & Mustika Icha Kurnia & 4 \\
\hline 21 & Putri Ayu Afriariska & 1 \\
\hline 22 & Qomarul Fitriani & - \\
\hline 23 & Qurrota 'Ayun & 1 \\
\hline 24 & Rizky Amalia Sari & 1 \\
\hline 25 & Ronaldo Candra Wijaya & - \\
\hline 26 & Siti Anita Indriyani & 2 \\
\hline 27 & Siti Sri Wahyuningsih & 1 \\
\hline 28 & Sony Budiarso & - \\
\hline 29 & Vicho Fahmi & 1 \\
\hline 30 & Zahro Qoryatina Putri & 1 \\
\hline \multicolumn{2}{|r|}{ Jumlah } & 32 \\
\hline
\end{tabular}


Tabel 7

Data Kesalahan Penggunaan Tanda Baca

dalam Menulis Pengalaman Pribadi

Siswa Kelas VII-B SMP Negeri 1 Rengel Kabupaten Tuban

\begin{tabular}{|c|c|c|}
\hline No & Nama & Kesalahan penggunaan tanda baca \\
\hline 1 & Aan Purnomo & \\
\hline 2 & G. Zulfan Baharuddin & - \\
\hline 3 & Alfiano Yanuar E. & - \\
\hline 4 & Arinda Ririn W. & - \\
\hline 5 & Arum Mita Elfani & - \\
\hline 6 & Cinta Damayanti & - \\
\hline 7 & Dewi Nur Cahyani & - \\
\hline 8 & Easter Victoria G. & - \\
\hline 9 & Elang Bangkit M. & 2 \\
\hline 10 & Ferdi Dwi Alfianto & - \\
\hline 11 & Galuh Indra P. & - \\
\hline 12 & Hendrik Arianto & - \\
\hline 13 & Herliana Helda Y. & - \\
\hline 14 & Intan Madya Kumala S. & - \\
\hline 15 & Kabul Budiono & - \\
\hline 16 & M. Rizkur Rofiq & - \\
\hline 17 & Melani Santoso & - \\
\hline 18 & M. Wais Alqorni & - \\
\hline 19 & M. Priyanto & 5 \\
\hline 20 & Mustika Icha Kurnia & - \\
\hline 21 & Putri Ayu Afriariska & - \\
\hline 22 & Qomarul Fitriani & - \\
\hline 23 & Qurrota 'Ayun & - \\
\hline 24 & Rizky Amalia Sari & - \\
\hline 25 & Ronaldo Candra Wijaya & - \\
\hline 26 & Siti Anita Indriyani & - \\
\hline 27 & Siti Sri Wahyuningsih & - \\
\hline 28 & Sony Budiarso & - \\
\hline 29 & Vicho Fahmi & - \\
\hline 30 & Zahro Qoryatina Putri & - \\
\hline \multicolumn{2}{|r|}{ Jumlah } & 5 \\
\hline
\end{tabular}


Tabel 8

Rekapitulasi Data Kesalahan Penggunaan Ejaan dan Tanda Baca dalam Menulis Pengalaman Pribadi

Siswa Kelas VII-B SMP Negeri 1 Rengel Kabupaten Tuban

\begin{tabular}{|c|c|c|c|c|c|}
\hline \multirow{2}{*}{ No } & \multirow{2}{*}{ Nama } & \multicolumn{3}{|c|}{ Kesalahan } & \multirow{2}{*}{ Jumlah } \\
\hline & & 1 & 2 & 3 & \\
\hline 1 & Aan Purnomo & & & & \\
\hline 2 & H. Zulfan Baharuddin & 2 & 2 & - & 4 \\
\hline 3 & Alfiano Yanuar E. & - & 1 & - & 1 \\
\hline 4 & Arinda Ririn W. & - & - & - & 0 \\
\hline 5 & Arum Mita Elfani & - & 1 & - & 1 \\
\hline 6 & Cinta Damayanti & - & - & - & 0 \\
\hline 7 & Dewi Nur Cahyani & - & 1 & - & 2 \\
\hline 8 & Easter Victoria G. & - & - & - & 0 \\
\hline 9 & Elang Bangkit M. & 5 & 3 & 2 & 10 \\
\hline 10 & Ferdi Dwi Alfianto & - & 2 & - & 2 \\
\hline 11 & Galuh Indra P. & 3 & 1 & - & 4 \\
\hline 12 & Hendrik Arianto & - & 2 & - & 2 \\
\hline 13 & Herliana Helda Y. & 2 & 1 & - & 3 \\
\hline 14 & Intan Madya Kumala S. & - & - & - & 0 \\
\hline 15 & Kabul Budiono & 7 & - & - & 7 \\
\hline 16 & M. Rizkur Rofiq & 2 & - & - & 2 \\
\hline 17 & Melani Santoso & - & 1 & - & 1 \\
\hline 18 & M. Wais Alqorni & 1 & 5 & - & 6 \\
\hline 19 & M. Priyanto & - & - & 5 & 5 \\
\hline 20 & Mustika Icha Kurnia & - & 4 & - & 4 \\
\hline 21 & Putri Ayu Afriariska & 2 & 1 & - & 3 \\
\hline 22 & Qomarul Fitriani & - & - & - & 0 \\
\hline 23 & Qurrota 'Ayun & 1 & 1 & - & 2 \\
\hline 24 & Rizky Amalia Sari & - & 1 & - & 1 \\
\hline 25 & Ronaldo Candra Wijaya & 1 & - & - & 1 \\
\hline 26 & Siti Anita Indriyani & 2 & 2 & - & 4 \\
\hline 27 & Siti Sri Wahyuningsih & - & 1 & - & 1 \\
\hline 28 & Sony Budiarso & 1 & - & - & 1 \\
\hline 29 & Vicho Fahmi & - & 1 & - & 1 \\
\hline 30 & Zahro Qoryatina Putri & - & 1 & - & 1 \\
\hline & Jumlah & 29 & 32 & 7 & \\
\hline
\end{tabular}

\section{Keterangan:}

1. Kesalahan penggunaan huruf kapital/kecil

2. Kesalahan penggunaan kata depan

3. Kesalahan penggunaan tanda baca 


\section{PEMBAHASAN}

Berdasarkan tabel-tabel tersebut dapat diberikan pembahasan sebagai berikut:

\section{Pelaksanaan Siklus I}

\section{a. Kesalahan Penggunaan Huruf Kapital}

Hasil tindakan siklus 1 menunjukkan bahwa jumlah siswa yang melakukan kesalahan penggunaan huruf kapital/kecil sebanyak 24 siswa $(82,75 \%)$. Kesalahan tersebut apabila diklasifikasikan adalah sebagai berikut: 1) siswa yang melakukan kesalahan penggunaan huruf kapital sebanyak 1-3 adalah 6 anak, 2) siswa yang melakukan kesalahan penggunaan huruf kapital sebanyak 4-6 adalah 4 anak, 3) siswa yang melakukan kesalahan penggunaan huruf kapital sebanyak 7-9 adalah 2 anak, 4) siswa yang melakukan kesalahan penggunaan huruf kapital sebanyak 10-12 adalah 2 anak, 5) siswa yang melakukan kesalahan penggunaan huruf kapital sebanyak 13-15 adalah 3 anak, 6) siswa yang melakukan kesalahan penggunaan huruf kapital sebanyak 19-21 adalah 3 anak, 7) siswa yang melakukan kesalahan penggunaan huruf kapital sebanyak 22-24 adalah 1 anak, 8) siswa yang melakukan kesalahan penggunaan huruf kapital sebanyak 28/lebih adalah 3 anak.

\section{b. Kesalahan Penggunaan Kata Depan}

Jumlah siswa yang melakukan kesalahan penggunaan kata depan adalah 23 anak (79,31\%). Kesalahan tersebut apabila diklasifikasikan adalah sebagai berikut: 1) siswa yang melakukan kesalahan penggunaan kata depan sebanyak 13 adalah 16 anak, 2) siswa yang melakukan kesalahan penggunaan kata depan sebanyak 4-6 adalah 3 anak, 3) siswa yang melakukan kesalahan penggunaan kata depan sebanyak 7-9 adalah 3 anak.

\section{c. Kesalahan Penggunaan Tanda Baca}

Jumlah siswa yang melakukan kesalahan penggunaan tanda baca adalah 24 anak $(82,75 \%)$. Kesalahan tersebut apabila diklasifikasikan adalah sebagai berikut: 1) siswa yang melakukan kesalahan penggunaan tanda baca sebanyak 13 adalah 13 anak, 2) siswa yang melakukan kesalahan penggunaan tanda baca sebanyak 4-6 adalah 7 anak, 3) siswa yang melakukan kesalahan penggunaan 
tanda baca sebanyak 7-9 adalah 2 anak, 4) siswa yang melakukan kesalahan penggunaan tanda baca sebanyak 10-12 adalah 2 anak.

\section{d. Hasil Catatan Lapangan}

Selama pelaksanaan tindakan dalam Siklus I ada beberapa catatan lapangan yang perlu disampaikan yaitu berupa kelebihan dan kekurangan teknik Jigsaw dalam pembelajaran menulis pengalaman pribadi. Berikut ini adalah temuan selama pelaksanaan tindakan oleh peneliti.

a) Kelebihan teknik Jigsaw dalam pembelajaran menulis pengalaman pribadi

(1) Siswa lebih tertarik dengan pembelajaran teknik Jigsaw

(2) Siswa lebih senang mengikuti pembelajaran dengan teknik Jigsaw

(3) Siswa lebih bersemangat mengikuti pembelajaran dengan teknik Jigsaw

(4) Siswa lebih mudah menemukan kaidah penggunaan ejaan dan tanda baca dengan pembelajaran teknik Jigsaw.

(5) Siswa dapat berdiskusi dengan teman untuk menentukan salah atau benar tentang penggunaan ejaan dan tanda baca dalam menulis pengalaman pribadi.

b) Kekuarangan teknik Jigsaw dalam pembelajaran menulis pengalaman pribadi

(1) Pengaturan kelas dalam kelompok-kelompok membutuhkan waktu sehingga mengurangi waktu kegiatan inti pembelajaran.

(2) Kegaduhan ketika siswa bergabung dengan kelompoknya belum sepenuhnya bisa dihindari.

(3) Belum semua siswa yang menjadi tim ahli dapat menyampaikan kaidah penggunaan ejaan dan tanda baca yang diperoleh dari guru kepada anggota kelompoknya dengan baik, sehingga pemahaman masing-masing anggota kelompok tidak sama.

(4) Masih banyak siswa yang ragu terhadap tulisan temannya, apakah tulisan tersebut menggunakan huruf kapital/kecil karena bentuk tulisan antara huruf besar/kecil dari teman tersebut hampir sama. Kondisi tersebut memicu si pengoreksi untuk mengonfirmasi kepada penulisnya. Tidak jarang terjadi bersitegang karena antara yang mengoreksi dan yang dikoreksi berbeda persepsi soal wujud huruf kapital/kecil. 
(5) Banyak siswa yang sebenarnya hanya melakukan satu kesalahan, misalnya penggunaan huruf kapital/kecil, namun jumlah kesalahannya menjadi banyak karena kesalahan tersebut dilakukan berulang-ulang.

(6) Masih ada siswa yang belum memahami kaidah penggunaan ejaan dan tanda baca dalam menulis pengalaman pribadi, sehingga ketika mengoreksi pekerjaan teman justru yang salah dibetulkan atau sebaliknya yang betul disalahkan. Hal ini menjadi tanggung jawab guru untuk melakukan koreksi ulang terhadap hasil kerja siswa.

Sesuai dengan pembahasan hasil penelitian tersebut, peneliti bersama kolaborator memutuskan untuk melanjutkan penelitian tindakan kelas pada siklus II dengan memperhatikan pada kelebihan dan kekurangan selama pelaksanaan siklus I.

\section{Pelaksanaan Siklus II}

\section{a. Kesalahan Penggunaan Huruf Kapital}

Jumlah siswa yang melakukan kesalahan penggunaan huruf kapital/kecil sebanyak 12 anak (41,37\%). Kesalahan tersebut apabila diklasifikasikan adalah sebagai berikut: 1) siswa yang melakukan kesalahan penggunaan huruf kapital sebanyak 1-3 adalah 10 anak, 2) siswa yang melakukan kesalahan penggunaan huruf kapital sebanyak 4-6 adalah 1 anak, 3) siswa yang melakukan kesalahan penggunaan huruf kapital sebanyak 7-9 adalah 1 anak.

\section{b. Kesalahan Penggunaan Kata Depan}

Jumlah siswa yang melakukan kesalahan penggunaan kata depan adalah 19 anak (65,51\%). Kesalahan tersebut apabila diklasifikasikan adalah sebagai berikut: 1) siswa yang melakukan kesalahan penggunaan kata depan sebanyak 13 adalah 17 anak, 2) siswa yang melakukan kesalahan penggunaan kata depan sebanyak 4-6 adalah 2 anak.

\section{c. Kesalahan penggunaan tanda baca}

Jumlah siswa yang melakukan kesalahan penggunaan tanda baca adalah 2 anak $(6,89 \%)$. Kesalahan tersebut apabila diklasifikasikan adalah sebagai berikut: 1) siswa yang melakukan kesalahan penggunaan tanda baca sebanyak 1-3 adalah 
1 anak, 2) siswa yang melakukan kesalahan penggunaan tanda baca sebanyak 46 adalah 1 anak.

Apabila dibandingkan dengan tindakan pada siklus I, hasil siklus II sudah menunjukkan adanya keberhasilan yang signifikan sebagai berikut: 1) siswa yang melakukan kesalahan penggunaan huruf kapital/kecil mengalami penurunan sebesar $41,38 \%$ yaitu dari $82,75 \%$ menjadi $41,37 \%, 2)$ siswa yang melakukan kesalahan penggunaan kata depan mengalami penurunan sebesar 13,80\% yaitu dari $79,31 \%$ menjadi $65,51 \%$, dan 3) siswa yang melakukan kesalahan penggunaan kata ulang mengalami penurunan sebesar $75,86 \%$ yaitu dari $82,75 \%$ menjadi $6,89 \%$.

Hasil tersebut sebagai bukti bahwa tindakan yang dilakukan telah dapat mengurangi tingkat kesalahan penggunaan ejaan dan tanda baca siswa kelas VII-B SMP Negeri 1 Rengel dalam menulis pengalaman pribadi. Hanya saja ada yang masih perlu mendapatkan perhatian dan tindak lanjut yaitu masalah penggunaan kata depan dalam menulis pengalaman pribadi masih mencapai $65,51 \%$.

Begitu pula mengenai jumlah kesalahan yang dilakukan oleh siswa apabila dibandingkan antara hasil siklus I dan siklus II dapat diketahui sebagai berikut: 1) jumlah kesalahan penggunaan huruf kapital/kecil mengalami penurunan sebesar 276 yaitu dari 305 menjadi 29, 2) jumlah kesalahan penggunaan kata depan mengalami penurunan sebesar 39 yaitu dari 71 menjadi 32, dan 3) jumlah kesalahan penggunaan tanda baca mengalami penurunan sebesar 82 yaitu dari 89 menjadi 7.

\section{d. Hasil Catatan Lapangan}

Selama pelaksanaan tindakan dalam Siklus II ada beberapa catatan lapangan yang perlu disampaikan yaitu berupa kelebihan dan kekurangan teknik Jigsaw dalam pembelajaran menulis pengalaman pribadi. Berikut ini adalah temuan selama pelaksanaan tindakan oleh peneliti.

a) Kelebihan teknik Jigsaw dalam pembelajaran menulis pengalaman pribadi

(1) Siswa lebih tertarik dengan pembelajaran teknik Jigsaw

(2) Siswa lebih senang mengikuti pembelajaran dengan teknik Jigsaw

(3) Siswa lebih bersemangat mengikuti pembelajaran dengan teknik Jigsaw 
(4) Siswa lebih mudah menemukan kaidah penggunaan ejaan dan tanda baca dengan pembelajaran teknik Jigsaw.

(5) Siswa dapat berdiskusi dengan teman untuk menentukan salah atau benar tentang penggunaan ejaan dan tanda baca dalam menulis pengalaman pribadi.

b) Kekuarangan teknik Jigsaw dalam pembelajaran menulis pengalaman pribadi yaitu walaupun jumlahnya lebih sedikit dibanding pada siklus I, beberapa siswa masih ragu terhadap tulisan temannya, apakah tulisan tersebut menggunakan huruf kapital/kecil karena bentuk tulisan antara huruf kapital/kecil dari teman tersebut hampir sama. Kondisi tersebut memicu si pengoreksi untuk mengonfirmasi kepada penulisnya.

Sesuai dengan pembahasan hasil penelitian tersebut, peneliti bersama kolaborator memutuskan untuk tidak melanjutkan penelitian tindakan kelas pada siklus berikutnya.

\section{SIMPULAN}

Sesuai dengan pembahasan hasil penelitian, akhirnya peneliti dapat memberikan kesimpulan sebagai berikut:

Terjadi peningkatan kemampuan menggunakan ejaan dan tanda baca dalam menulis pengalaman pribadi dengan teknik Jigsaw siswa kelas VII-B SMP Negeri 1 Rengel Kabupaten Tuban yaitu: 1) siswa yang melakukan kesalahan penggunaan huruf kapital/kecil mengalami penurunan sebesar $41,38 \%$ yaitu dari $82,75 \%$ menjadi $41,37 \%, 2)$ siswa yang melakukan kesalahan penggunaan kata depan mengalami penurunan sebesar $13,80 \%$ yaitu dari $79,31 \%$ menjadi $65,51 \%$, dan 3) siswa yang melakukan kesalahan penggunaan tanda baca mengalami penurunan sebesar $75,86 \%$ yaitu dari $82,75 \%$ menjadi $6,89 \%$.

\section{DAFTAR PUSTAKA}

Afra, Afifah. 2007. How To Be A Smart Writer. Surakarta: Indiva Media Kreasi.

Badan Standar Nasional Pendidikan. 2006. Panduan Penyusunan Kurikulum Tingkat Satuan Pendidikan Jenjang Pendidikan Dasar dan Menengah.

Depdiknas. 2006. Standar Kompetensi Mata Pelajaran Bahasa dan Sastra Indonesia SMP/MTs. 
Hasnun, H. Anwar. 2006. Pedoman Menulis untuk Siswa SMP dan SMA. Yogyakarta: Andi.

Lie, Anita. 2003. Cooperative Learning: Mempraktikkan Cooperative Learning di Ruang-Ruang Kelas (cetakan kedua). Jakarta: Grasindo.

O’Malley, J. Michael dan Pierce, Lorraine Valdez. 1996. Authentic Assessment For English Language Learnes: Practical Approaches For Teachers. USA: Addison-Wesley Publishing Company.

Pusat Pembinaan dan Pengembangan Bahasa Depdiknas. 2007. Pedoman Umum Ejaan Bahasa Indonesia yang Disempurnakan. Yogyakarta: Indonesiatera.

Riyanto, Yatim. 2007. Metodologi Penelitian Pendidikan Kualitatif dan Kuantitatif. Surabaya: Unesa University Press.

Slavin, Robert E. 1995. Cooperative Learning: Theory Research and Practice. Massachusetts: Allyn and Bacon.

Standar Nasional Pendidikan (SNP). 2006. Jakarta: Asa Mandiri.

Suparno dan Yunus, Mohamad. 2003. Keterampilan Dasar Menulis. Jakarta: Pusat Penerbitan Universitas Terbuka.

Yulianto, Bambang. 2008. Aspek Kebahasaan dan Pembelajarannya. Surabaya: Unesa University Press. 